\title{
PENERAPAN MODEL PROBLEM-BASED LEARNING UNTUK MENINGKATKAN KETERAMPILAN BERPIKIR KRITIS DAN HASIL BELAJAR SISWA
}

\author{
Yunin Nurun Nafiah \\ Program Studi Pendidikan Teknologi dan Kejuruan PPs UNY \\ mafaza_2909@yahoo.co.id \\ Wardan Suyanto \\ Universitas Negeri Yogyakarta \\ wardansuyanto@uny.ac.id
}

\begin{abstract}
Abstrak
Penelitian ini bertujuan untuk meningkatkan keterampilan berpikir kritis dan hasil belajar siswa Sekolah Menengah Kejuruan (SMK) kelas X Teknik Komputer Jaringan (TKJ) dalam pembelajaran Perbaikan dan Setting Ulang PC melalui penerapan model Problem-Based Learning (PBL). Penelitian ini adalah penelitian tindakan kelas. Subjek penelitian adalah siswa kelas X kompetensi keahlian TKJ. Pengumpulan data menggunakan metode observasi dengan instrumen checklist dan tes unjuk kerja. Data yang diperoleh dianalisis secara deskriptif. Hasil penelitian menunjukkan sebagai berikut: (a) penerapan model PBL dalam pembelajaran materi perbaikan dan setting ulang PC dapat meningkatkan keterampilan berpikir kritis siswa dalam pembelajaran yaitu sebesar 24,2\%, (b) Keterampilan berpikir kritis siswa setelah penerapan PBL yaitu siswa dengan kategori keterampilan berpikir kritis sangat tinggi sebanyak 20 siswa (69\%), kategori tinggi sebanyak 7 siswa (24,2\%), kategori rendah sebanyak 2 siswa (6,9\%) dan kategori sangat rendah yaitu sebanyak 0 siswa (0\%), (c) penerapan PBL dapat meningkatkan hasil belajar siswa sebesar 31,03\%, dan (d) Hasil belajar siswa setelah penerapan PBL yakni jumlah siswa yang mencapai KKM sebanyak 29 siswa (100\%).
\end{abstract}

Kata kunci: problem-based learning, keterampilan berpikir kritis, hasil belajar

\section{THE APPLICATION OF THE PROBLEM-BASED LEARNING MODEL TO IMPROVE THE STUDENTS CRITICAL THINKING SKILLS AND LEARNING OUTCOMES}

\begin{abstract}
This study aims to improve the critical thinking skills and learning outcomes of Grade X students of Network Computer Engineering (NCE) of vocational high schools (VHSs) in the learning of PC repair and re-setting through the application of the Problem-Based Learning (PBL) model. This was a classroom action research. The study involve Grade X students of the NCE expertise competency as the research subjects. The data were collected through observation with a checklist instrument and a performance test. They were descriptively analyzed. The results of the study show that: (a) the application of the PBL model is capable of improving the students' critical thinking skills in the learning of PC repair and re-setting at 24.2\%,(b) the students'critical thinking skills in the learning of $P C$ repair and re-setting after the application of the PBL model is categories of critical thinking skills is very high as 20 students (69\%), high categories as 7 students (24.2\%), low categories as 2 student (6.9\%) and very low categories as 0 student (0\%), (c) the application of PBL model is capable of improving the the students'learning outcomes in the learning of $P C$ repair and re-setting at $31.03 \%$, and (d) the students'learning outcomes after the application of the PBL model namely the number of students who reach the KKM as much as 29 students (100\%).
\end{abstract}

Keywords: problem-based learning, critical thinking skills, learning outcomes 


\section{PENDAHULUAN}

Perjanjian ASEAN Free Trade Area (AFTA) yang telah berjalan hingga saat ini merupakan bagian dari adanya era globalisasi yang memberi dampak terhadap persaingan yang ketat. Persaingan tersebut tidak hanya dalam perdagangan dan industri tetapi juga persaingan sumber daya manusia. Dampak diberlakukannya AFTA memungkinkan arus tenaga kerja dari negara-negara ASEAN tanpa hambatan birokrasi yang berarti, sehingga orang yang tidak mempunyai kompetensi pada bidang tertentu tidak mungkin dapat bersaing dalam memperoleh lapangan pekerjaan. Oleh sebab itu peningkatan kemampuan dan kompetensi Sumber Daya Manusia (SDM) Indonesia menjadi hal yang tidak dapat ditawar lagi.

Diberlakukannya AFTA dan globalisasi seperti yang dikemukakan diatas, menjadi tantangan yang besar bagi lulusan SMK. Dengan adanya persaingan tersebut SMK dituntut untuk selalu meningkatkan kualitas lulusan sehingga para lulusan mampu bersaing di dunia kerja. Untuk menghasilkan kualitas lulusan SMK yang kompeten, salah satunya dipengaruhi oleh keberhasilan dalam proses pembelajaran. Karakteristik pembelajaran di SMK berbeda dengan pembelajaran di SMA. Pada proses pembelajaran di SMK menitikberatkan pada penguasaan pengetahuan, keterampilan, sikap dan nilai-nilai yang dibutuhkan oleh dunia industri. Dalam pembelajaran di SMK kegiatan belajar mengajar memiliki porsi yang lebih banyak dilakukan di laboratorium/ bengkel sebagai bentuk pembelajaran praktek. Kegiatan tersebut bertujuan agar siswa dapat menguasai masing-masing kompetensi. Salah satu Standar Kompetensi Lulusan (SKL) pada satuan pendidikan Sekolah Menengah Kejuruan/Madrasah Aliyah Kejuruan (SMK/MAK) yaitu menunjukkan kemampuan berpikir logis, kritis, kreatif, dan inovatif dalam pengambilan keputusan (Lampiran Permendiknas No.23 Tahun 2006). Kompetensi-kompetensi tersebut diperlukan pada saat siswa memasuki dunia usaha/dunia industri yang ditetapkan dalam kompetensi kunci dan harus dimiliki oleh setiap tenaga kerja. Oleh karena itu, perlu diperhatikan dalam pembelajaran.
Hasil penelitian dari Kay (2008), menganalisis perkembangan yang akan terjadi di abad 21 dan mengidentifikasi 5 kondisi atau konteks baru dalam kehidupan, yang masing-masing memerlukan kompetensi tertentu. Kondisi tersebut antara lain: (1) kondisi kompetisi global (perlu adanya kesadaran global dan kemandirian), (2) kondisi kerjasama global (perlu kesadaran global, kemampuan bekerjasama, penguasaan Information Communication and Technology (ICT), (3) pertumbuhan informasi (perlu melek teknologi, critiacal thinking \& pemecahan masalah), (4) perkembangan kerja dan karier (perlu critical thinking \& pemecahan masalah, innovasi \& penyempurnaan, dan, fleksibel \& adaptable), (5) perkembangan ekonomi berbasis pelayanan jasa, knowledge economy (perlu melek informasi, critical thinking dan pemecahan masalah). Selanjutnya Kay menyatakan bahwa, dalam lima tahun kedepan terdapat keterampilan yang amat penting, yaitu berpikir kritis (78\%), (IT 77\%), kesehatan dan kebugaran (76\%), inovasi $(74 \%)$, dan tanggung jawab keuangan pribadi (72\%).

SMK Islam Terpadu Smart Informatika Surakarta (SMKITSI) merupakan SMK dengan kompetensi keahlian Teknik Komputer dan Jaringan (TKJ) yang saat ini masih memiliki kesulitan dalam pembelajaran praktik perbaikan dan setting ulang PC. Permasalahan yang disampaikan oleh industri sebagai mitra prakerind yaitu siswa masih kurang kreatif dalam menyelesaikan pekerjaan yang diberikan. Pihak industri menyampaikan, ketika siswa diberikan pekerjaan untuk memperbaiki PC siswa memiliki kesulitan dalam mengidentifikasi kerusakan PC yang dihadapi, sehingga ketika menentukan perbaikan yang harus dilakukan menjadi ragu-ragu.

Permasalahan yang disampaikan $\mathrm{d}$ iatas menunjukkan bahwa siswa masih kesulitan dalam menyelesaikan pekerjaan yang diberikan. Artinya, dalam melaksanakan pekerjaan tersebut siswa belum terampil dalam melakukan tahapan-tahapan yang harus dilakukan dalam perbaikan PC. Proses perbaikan PC melibatkan keterampilan menganalisis dan juga membuat keputusan tepat berdasarkan hasil analisa. Keterampilan-keterampilan terse- 
but termasuk kategori berpikir kritis. Berpikir kritis merupakan proses merumuskan alasan yang tertib secara aktif dan terampil dari menyusun konsep,mengaplikasikan, menganalisis, mengintegrasikan (sintesis), atau mengevaluasi informasi yang dikumpulkan melalui proses pengamatan, pengalaman, refleksi, pemberian alasan (reasoning) atau komunikasi sebagai dasar dalam menentukan tindakan. Berpikir kritis sangat penting dimiliki oleh siswa, karena memungkinkan siswa untuk dapat menyelesaikan masalah sosial, keilmuan dan permasalahan praktis secara efektif. Pada era seperti sekarang ini, adanya pengetahuan dan informasi belum cukup untuk menyelesaikan masalah. Untuk dapat bekerja dengan efektif didunia kerja dan dalam kehidupan sehari-hari siswa harus dapat menyelesaikan permasalahan untuk dapat membuat keputusan yang tepat, maka

Salah satu Standar Kompetensi (SK) yang harus dikuasai oleh siswa SMK TKJ adalah materi SK perbaikan dan setting ulang sistem PC yang terdiri dari tiga kompetensi dasar yaitu, menjelaskan langkah perbaikan, melaksanakan perbaikan PC dan memeriksa hasil perbaikan. Materi perbaikan PC terdiri dari menjelaskan langkah-langkah perbaikan, yaitu diawali dari mendiagnosa kerusakan, menemukan dan mengisolasi permasalahan, melaksanakan perbaikan dan memeriksa hasil perbaikan.

Pembelajaran praktik yang selama ini dilaksanakan belum optimal. Hal ini dikarenakan ada siswa yang dominan dan aktif dan ada siswa yang cenderung pasif, sehingga pembelajaran belum bisa maksimal. Permasalahan kerusakan PC yang dipelajari siswa belum banyak jenisnya sehingga pada saat prakerind siswa mengalami kesulitan. Hasil tes praktek siswa pada tahun ajaran 2011/2012 menunjukkan bahwa pada SK4 pada kelas XA berjumlah 19 siswa (63\%) dan pada kelas XB berjumlah 13 siswa $(44,8 \%)$ belum tuntas sehingga guru melaksanakan remidial beberapa kali. Selain itu dalam pembelajaran praktek belum dapat memberi kesempatan kepada siswa mengembangkan komunikasi dalam menyampaikan hasil praktek yang informatif.

Berdasarkan hal diatas menunjukkan bahwa hasil belajar siswa masih kurang, salah sa- tunya dipengaruhi oleh penguasaan siswa pada materi langkah-langkah perbaikan PC. Siswa mengungkapkan bahwa materi perbaikan PC adalah materi yang sulit dan kompleks. Evaluasi yang dilakukan oleh guru bahwa metode pembelajaran dengan demonstrasi belum cukup efektif. Selama ini, dalam proses pembelajaran kasus kerusakan PC yang diberikan masih sederhana, padahal jika suatu PC memiliki kerusakan yang kompleks gejala yang muncul pada saat diagnosa seringkali berbeda. Sehingga siswa masih kesulitan jika dihadapkan pada permasalahan yang nyata. Melalui penggunaan keterampilan berpikir kritis, siswa akan terbantu dalam proses mengidentifikasi kerusakan PC. Dari hasil identifikasi yang akurat maka akan ditemukan langkah perbaikan PC yang tepat.

Untuk dapat membangun keterampilan berpikir kritis, guru dapat memberikan pengalaman belajar dengan mendesain proses pembelajaran. Guru mendesain pembelajaran dengan memberikan permasalahan yang melibatkan keterampilan berpikir siswa dan melibatkan proses menganalisis berdasarkan permasalahan yang sebenarnya. Salah satu model pembelajaran yang dapat diterapkan adalah Problem Based Learning (PBL) atau pembelajaran berbasis masalah. Menurut Glazer (2001) menyatakan bahwa PBL menekankan belajar sebagai proses yang melibatkan pemecahan masalah dan berpikir kritis dalam konteks yang sebenarnya. Glazer selanjutnya mengemukakan bahwa PBL memberikan kesempatan kepada siswa untuk mempelajari hal lebih luas yang berfokus pada mempersiapkan siswa untuk menjadi warga negara yang aktif dan bertanggung jawab. Melalui PBL siswa memperoleh pengalaman dalam menangani masalah-masalah yang realistis, dan menekanan pada penggunaan komunikasi, kerjasama, dan sumber-sumber yang ada untuk merumuskan ide dan mengembangkan keterampilan penalaran. Hasil penelitian Abdullah dan Ridwan (2008) menyatakan model PBL dapat meningkatkan hasil belajar siswa pada aspek kognitif, afektif dan psikomotorik. Penelitian Hasrul Bakri (2009), menyatakan bahwa PBL mampu meningkatkan minat belajar praktek menggulung trafo. Hasil penelitian Oon-Seng Tan (2008) menyatakan PBL dapat mengantar- 
kan siswa untuk menyelesaikan permasalahan hidup melalui proses menemukan, belajar dan berpikir secara independen. Melihat karakteristik dari PBL, model pembelajaran tersebut sesuai jika diterapkan pada pembelajaran materi perbaikan dan setting ulang PC.

Sesuai dengan latar belakang diatas, penelitian ini bertujuan untuk: (1) meningkatkan keterampilan berpikir kritis siswa pada materi Perbaikan dan Setting Ulang PC melalui penerapan model problem based learning; (2) meningkatkan hasil belajar siswa pada materi Perbaikan dan Setting Ulang PC melalui penerapan model problem based learning; (3) mengetahui keterampilan berpikir kritis siswa pada materi Perbaikan dan Setting Ulang PC setelah penerapan model probem based learning; (4) mengetahui hasil belajar siswa pada materi Perbaikan dan Setting Ulang PC setelah penerapan model probem based learning.

\section{Belajar dan Pembelajaran di Sekolah Menengah Kejuruan}

Dimyati dan Mudjiono (2009: 9) mengemukakan bahwa belajar adalah suatu perilaku. Dalam belajar ditemukan adanya (1) kesempatan terjadinya peristiwa yang dapat menimbulkan respon, (2) respon siswa, (3) konsekuensi yang menguatkan respon tersebut. Menurut Oemar Hamalik (2011: 27-28), menyatakan bahwa (1) belajar adalah modifikasi atau memperteguh kelakuan melalui pengalaman, belajar merupakan suatu proses, suatu kegiatan dan bukan suatu hasil atau tujuan. Dalam proses belajar yakni siswa mengalami secara langsung proses belajar, tidak sekedar menerima pengetahuan saja, (2) belajar merupakan suatu proses perubahan tingkah laku individu melalui interaksi dengan lingkungan. Adanya interaksi siswa dengan lingkungan akan menimbulkan pengalaman belajar. Karena belajar merupakan proses untuk mencapai tujuan, maka dalam belajar terdapat langkah-langkah atau prosedur yang harus ditempuh. Menurut Winkel (2009: 59), belajar adalah semua aktivitas mental atau psikis yang berlangsung dalam interaksi aktif dalam lingkungan, yang menghasilkan perubahan-perubahan dalam pengetahuan pemahaman, keterampilan dan nilai sikap. Perubahan itu bersifat relatif konstan dan berbekas. Dalam proses belajar terdapat interaksi antara siswa dengan lingkungan belajar, dalam bergaul dengan orang, berinteraksi dengan benda-benda serta menghadapi peristiwa-peristiwa yang diberikan dalam proses belajar.

Pembelajaran di SMK dilaksanakan dalam kerangka pembentukan Standar Kompetensi Lulusan (SKL) peserta didik. Pembelajaran di SMK menggunakan paradigma outcome yaitu kompetensi apa yang harus dikuasai peserta didik bukan pembelajaran yang memaksakan apa yang harus diajarkan oleh seorang guru (Putu Sudira, 2006: 9-10). Pavlova (2009: 7) menyatakan, "Traditionally, direct preparation for work was the main goal of vocational education". Pernyataan Pavlova tersebut mengandung makna bahwa tujuan utama dari pendidikan kejuruan adalah mempersiapkan peserta didik untuk memasuki dunia kerja. Berdasarkan hal tersebut, maka dalam proses pembelajaran yang dilaksanakan di SMK memiliki porsi yang lebih banyak dalam pembelajaran praktik untuk membekali keterampilan.

\section{Keterampilan Berpikir Kritis (Critical Thinking Skill)}

Berpikir merupakan aktivitas yang melibatkan proses memanipulasi dan merubah informasi yang ada dalam ingatan. Pada saat berpikir, kita berpikir untuk membentuk suatu konsep, pertimbangan, berpikir kritis, membuat keputusan, berpikir kreatif dan memecahkan masalah. Menurut R.Ennis dalam Nitko dan Brookhart (2011:232):

.....Critical thinking is reasonable, reflective thinking that is focused on deciding what to belief or do...

Berpikir kritis bersifat reasonable dan berpikir reflektif yang difokuskan pada memutuskan apa yang harus dipercayai dan apa yang harus dilakukan. Artinya ketika menggunakan berpikir kritis akan dapat memutuskan dengan tepat apa yang seharusnya dipercayai dan apa yang harus dilakukan. Berpikir kritis merupakan proses intelektual dan penuh konsep akan keterampilan yaitu (1) mengaplikasikan; (2) menganalisa; (3) mensintesa; (4) mengevaluasi darimana suatu informasi diperoleh; (5) atau men-generalisasi hasil dari proses observasi, pengalaman, refleksi, penalaran, atau komunikasi sebagai dasar untuk dipercaya dan apa 


\begin{tabular}{|ll|}
\hline \multicolumn{2}{|c|}{ Essential Intellectual Standards } \\
\hline Clarity & Precision \\
Accuracy & Significance \\
Relevance & Completeness \\
Logical Validity & Fairness \\
Breadth & Depth \\
\hline
\end{tabular}

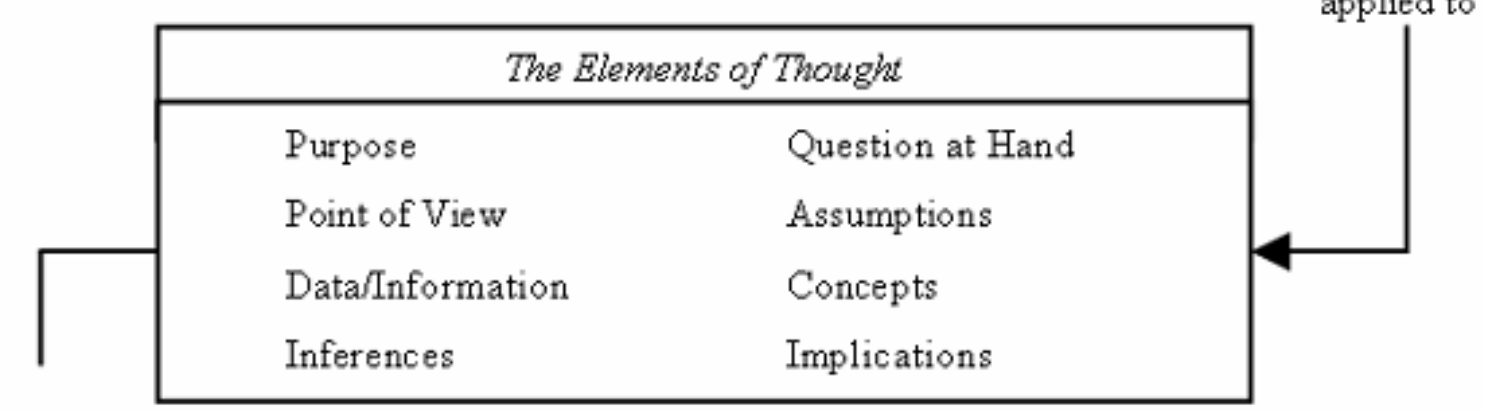

to de velop

\begin{tabular}{|ll|}
\hline \multicolumn{2}{|c|}{ Intellectual Traits/Virtues } \\
\hline Intellectual Humility & Perseverance \\
Intellectual Autonomy & Confidence in Reason \\
Intellectual Integrity & Intellectual Empathy \\
Intellectual Courage & Fair-mindedness \\
\hline
\end{tabular}

Gambar 1.Model Berpikir Kritis Richard Paul

(Sumber: Richard Paul \& Linda Elder, 2008)

yang akan dilakukan (Paul, 2008: 4). Seorang pemikir kritis menerapkan standar-standar berpikir pada elemen-elemen penalaran dalam mengembangkan ciri-ciri intelektual. Standar intelektual harus diterapkan pada elemenelemen berpikir sebagai proses belajar dalam mengembangkan ciri-ciri intelektual. Pada gambar 1 berikut adalah model berpikir kritis yang dikemukakan oleh Richard Paul,

Pada saat berpikir, seorang insinyur menerapkan standar intelektual berikut dalam mengembangkan berpikir kritis (1) clarity (kejelasan); (2) accuracy (ketepatan); (3) precision (ketelitian); (4) completeness (kelengkapan); (5) relevance (relevan); (6) Significance (bermakna);(7)logicalness (logis); (8) depth (kedalaman); (9) breadth (keluasan); (10) fair- ness (terbuka). Menurut Paul \& Elder (2008), seseorang dikatakan berpikir kritis yang baik jika: (1)Mengajukan pertanyaan penting terhadap masalah; (2) Mengumpulkan dan menilai informasi yang relevan; (3) Membuat kesimpulan dan solusi dengan penalaran yang tepat; (4) Berpikir dengan pikiran terbuka; (5) Berkomunikasi efektif dalam menyampaikan solusi dari permasalahan.

\section{Model Pembelajaran Problem Based Learning}

Problem Based Learning adalah seperangkat model mengajar yang menggunakan masalah sebagai fokus untuk mengembangkan keterampilan pemecahan masalah, materi, dan pengaturan-diri (Hmelo-Silver, 2004; Se- 
rafino\& Cicchelli, 2005, Egen dan Kauchak, 2012: 307). PBL merupakan suatu pendekatan pembelajaran yang menggunakan masalah dunia nyata sebagai suatu konteks bagi peserta didik untuk belajar tentang cara berpikir kritis dan keterampilan pemecahan masalah, serta untuk memperoleh pengetahuan dan konsep yang esensial dari materi pelajaran. PBL merupakan pembelajaran berdasarkan teori kognitif yang didalamnya termasuk teori belajar konstruktivisme. Menurut teori konstruktivisme, keterampilan berpikir dan memecahkan masalah dapat dikembangkan jika peserta didik melakukan sendiri, menemukan, dan memindahkan kekomplekan pengetahuan yang ada.

Anita Woolfolk (2007:352) mengatakan:

The goals of problem based learning are to help students develop flexible knowledge that can be applied in many situations, in contrast to inert knowledge. .... other goals of problem based learning are to enhance intrinsic motivation and skills in problem solving, collaboration, and self directed lifelong learning.

Menurut Arends (2008:55), langkahlangkah dalam melaksanakan PBL ada 5 fase yaitu (1) mengorientasi siswa pada masalah; (2) mengorganisasi siswa untuk meneliti; (3) membantu investigasi mandiri dan berkelompok; (4) mengembangkan dan menyajikan hasil karya; (5) menganalisis dan mengevaluasi proses pemecahan masalah., permasalahan yang digunakan dalam PBL adalah permasalahan yang dihadapi di dunia nyata. Meskipun kemampuan individual dituntut bagi setiap siswa, tetapi dalam proses belajar dalam PBL siswa belajar dalam kelompok untuk memahami persoalan yang dihadapi. Kemudian siswa belajar secara individu untuk memperoleh informasi tambahan yang berhubungan dengan pemecahan masalah. Peran guru dalam PBL yaitu sebagai fasilitator dalam proses pembelajaran.

\section{Keterkaitan PBL dan Berpikir Kritis}

Scriven \& Paul (2008) mengungkapkan bahwa dalam berpikir kritis terdapat keterampilan mengaplikasikan, menganalisa, mensintesa, mengevaluasi informasi yang diperoleh dan mengeneralisasi hasil yang diperoleh dari observasi, pengalaman, refleksi, penalaran, atau komunikasi. Berpikir kritis tidak serta merta melekat pada seseorang sejak lahir. Akan tetapi, berpikir kritis merupakan keterampilan yang dapat dikembangkan melalui pengalaman langsung siswa dalam menghadapi permasalahan. Sehingga, jika siswa terbiasa menggunakan keterampilan diatas maka keterampilan berpikir kritis akan dapat berkembang. Tugas guru dalam rangka meningkatkan keterampilan berpikir kritis siswa adalah dengan menyediakan lingkungan belajar yang dapat mendorong siswa menggunakan keterampilan berpikir. Model pembelajaran PBL adalah salah satu model pembelajaran yang dapat menyediakan lingkungan belajar yang mendukung berpikir kritis. PBL didasarkan pada situasi bermasalah dan membingungkan sehingga akan membangkitkan rasa ingin tahu siswa sehingga siswa tertarik untuk menyelidiki permasalahan tersebut. Pada saat siswa melakukan penyelidikan, maka siswa menggunakan tahapan berpikir kritis untuk menyelidiki masalah, menganalisa berdasarkan bukti dan mengambil keputusan berdasarkan hasil penyelidikan.

Dalam website yang mengembangkan keterampilan berpikir kritis menyatakan .... $P B L$ can help students develop communication, reasoning and critical thinking skills (http://depts.washington.edu/cidrweb). Dalam hasil penelitian dari I Wayan Sadia (2008), menurut persepsi guru model pembelajaran yang dipandang dapat memberi kontribusi dalam mengembangkan keterampilan berpikir kritis adalah pembelajaran kontekstual, model pembelajaran berbasis masalah (pbl), model problem solving, model sains-teknologi masyarakat, model siklus belajar dan model pembelajaran berbasis penilaian portofolio. Kenneth J. Oja (2011), menyatakan bahwa terdapat hubungan positif antara penerapan PBL terhadap keterampilan berpikir kritis siswa keperawatan. Tetapi perlu diperketat dalam penggunaan PBL untuk mengevaluasi berpikir kritis.

\section{Keterkaitan PBL dan Hasil Belajar}

Orhan \& Ruhan (2007), menyatakan bahwa model PBL memberikan dampak positif pada prestasi akademik siswa dan sikap siswa terhadap sains. Dalam pelaksanaan PBL 
di sekolah kesehatan, PBL memberi dampak positif terhadap kompetensi dokter dalam dimensi sosial dan kognitif (Gerald Choon-Huat Koh, Hoon Eng Khoo, Mee Lian Wong \& David Koh,2008). Dalam penelitian yang dilaksanakan oleh Hasrul Bakri (2009), menunjukkan bahwa penerapan PBL di SMK dalam pembelajaran praktek dapat meningkatkan minat dan kemampuan praktek siswa dalam praktek menggulung trafo. Penelitian Ade Gafar Abdullah dan Taufik Ridwan (2008), menyatakan bahwa dalam penerapan PBL terdapat peningkatan hasil belajar siswa.

\section{METODE PENELITIAN}

Metode penelitian yang digunakan adalah penelitian tindakan kelas (PTK). Desain PTK dalam penelitian ini menggunakan model yang dikemukakan oleh Kemmis dan Mc Taggart (Mc Taggart, 1983:4), yang terdiri dari 4 tahapan yaitu perencanaan, pelaksanaan, pengamatan dan refleksi. Model PTK berbentuk spiral dan berkelanjutan apabila target hasil tindakan yang dilakukan belum tercapai maka dilanjutkan dengan siklus berikutnya. Desain PTK model Kemmis dan Mc Taggart seperti pada gambar2.

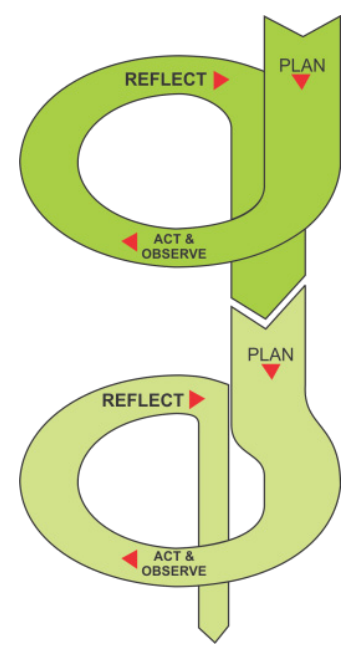

Gambar 2. Modelpenelitian tindakan dari Kemmis dan Mc Taggart

Penelitian ini melibatkan seorang kolaborator yaitu guru produktif Teknik Komputer Jaringan (TKJ). Kolaborator bertugas membantu peneliti dalam melaksanakan pembelajaran dengan PBL dan mengobservasi siswa pada saat pembelajaran.

\section{Waktu dan Tempat Penelitian}

Penelitian ini dilaksanakan pada bulan Mei sampai dengan Juni 2013. Hal ini disesuaikan dengan materi perbaikan dan setting ulang PC yang disampaikan pada semester genap tahun ajaran 2012/2013. Penelitian bertempat di SMK Islam Terpadu Smart Informatika Surakarta yang beralamat di Jl. Sri Gunting VII, No IX, Gremet Manahan Surakarta.

\section{Subjek Penelitian}

Subjek dalam peneitian ini adalah siswa kelas XB SMK IT SI, dimana siswa tersebut pada semester genap memperoleh materi perbaikan dan setting ulang PC.

\section{Prosedur}

Prosedur penelitian ini, dalam satu siklus terdiri dari 4 tahap yaitu perencanaan, pelaksanaan, pengamatan dan refleksi. Tahapan perencanaan ini disusun rencana tindakan yang akan dilakukan untuk meningkatkan keterampilan berpikir kritis dan hasil belajar siswa melalui penerapan model PBL. Perencanaan tindakan terdiri dari mempersiapkan jadwal pembelajaran PBL, RPP, perangkat pembelajaran PBL, persiapan peralatan dan bahan praktik, media pembelajaran yang digunakan, sosialisasi pembelajaran dengan PBL kepada siswa dan mempersiapkan instrumen penelitian. Pada tahap ini peneliti melaksanakan pembelajaran yang telah direncanakan. Guru melaksanaan pembelajaran bekerjasama dengan kolaborator dalam penerapan model PBL. Dalam PBL terdapat 5 fase yang harus dilaksanakan beroso aktivitas guru dan siswa. Secara rinci disajikan pada tabel 1.

Tahapan observasi dilakukan oleh peneliti bekerjasama dengan kolaborator untuk mengamati secara langsung pada saat proses pembelajaran berlangsung. Peneliti bertindak sebagai guru pengajar dibantu oleh kolaborator. Observasi bertujuan untuk mengetahui ada atau tidaknya perubahan yang terjadi dengan adanya pelaksanaan tindakan yang sedang dilaksanakan yaitu penerapan model PBL. Tahap refleksi tindakan yakni mengevaluasi dari hasil pelaksanaan tindakan. Refleksi didasarkan dari data yang terkumpul berupa hasil observasi dan penilaian. Hasil refleksi dijadikan sebagai dasar untuk penentuan dilaksanakan atau tidak tindakan pada siklus selanjutnya. 
Tabel 1. Fase dalam PBL

\begin{tabular}{ll}
\hline Fase dalam PBL & Perilaku Guru \\
\hline Fase 1 & Guru membahas tujuan pembelajaran, mendeskripsikan berbagai \\
Memberikan orientasi tentang & $\begin{array}{l}\text { kebutuhan logistik penting, dan memotivasi siswa untuk terlibat } \\
\text { permasalahannya kepada siswa }\end{array}$
\end{tabular}

\section{Fase 2}

Mengorganisasikan siswa untuk meneliti

Guru membantu siswa untuk mendefinisikan dan mengorganisasikan tugas-tugas belajar yang terkait dengan permasalahannya Guru mendorong siswa untuk mendapatkan informasi yang tepat, melaksanakan eksperimen, dan mencari penjelasan dan solusi

Membantu investigasi mandiri dan berkelompok;

\begin{tabular}{|c|c|}
\hline $\begin{array}{l}\text { Fase } 4 \\
\text { Mengembangkan dan mempre- } \\
\text { sentasikan artefak/exhibit }\end{array}$ & $\begin{array}{l}\text { Guru membantu siswa dalam merencanakan dan menyiapkan } \\
\text { artefak-artefak yang tepat seperti laporan, rekaman video, dan } \\
\text { model-model yang membantu mereka untuk menyampaikannya } \\
\text { kepada orang lain. }\end{array}$ \\
\hline Fase 5 & membantu siswa untuk melakukan refleksi terhadap inves- \\
\hline $\begin{array}{l}\text { Menganalisis dan mengevalu- } \\
\text { asi proses mengatasi masalah }\end{array}$ & $\begin{array}{l}\text { tigasinya (penyelidikannya) dan proses-proses yang mereka gu- } \\
\text { nakan. }\end{array}$ \\
\hline
\end{tabular}

\section{Intrumen, dan Teknik Pengumpulan Data}

Data yang diperoleh dalam penelitian ini berupa data kuantitatif berupa hasil observasi aktivitas guru dan siswa dalam PBL, keterampilan berpikir kritis siswa, dan hasil belajar siswa pada materi perbaikan dan setting ulang PC. Teknik pengumpulan data yang digunakan adalah observasi dengan menggunakan instrumen checklist dan tes unjuk kerja.

\section{Teknik Analisis Data}

Penelitian tindakan kelas merupakan penelitian kasus disuatu kelas yang hasilnya tidak untuk digeneralisasikan, maka analisis data cukup dengan mendeskripsikan data yang terkumpul. Teknik statistik yang digunakan adalah statistik deskriptif. Masing-masing variabel penelitian dianalisis dengan mengacu pada kriteria yang ditetapkan.

\section{HASIL PENELITIAN DAN PEMBAHASAN}

\section{Deskripsi Data}

Prosedur dari penelitian yang dilakukan menggunakan prosedur penelitian tindakan kelas dari Kemmis dan Mc Taagart terdiri dari tahapan perencanaan, pelaksanaan, observasi dan refleksi. Pada setiap tahapan kegiatan, peneliti senantiasa melakukan bersama kolaborator yaitu guru produktif TKJ. Kolaborator berperan sebagai tim dalam pembelajaran dengan PBL dan juga membantu dalam kegiatan observasi dikelas. Penelitian tindakan kelas yang telah dilakukan terdiri dari 2 siklus, yang dilaksanakan mulai tanggal 7 Mei 2013 sampai dengan 28 Mei 2013.

Tindakan yang diberikan berupa penerapan model PBL dalam proses pembelajaran materi perbaikan dan setting ulang PC. Pembelajaran dengan PBL dilaksanakan melalui 5 fase yang terdiri dari (1)Fase1: Memberikan orientasi tentang permasalahan kepada siswa; (2) Fase2: Mengorganisasi siswa untuk meneliti; (3) Fase3: Membantu investigasi mandiri dan berkelompok; (4) Fase 4: Mengembangkan dan menyajikan hasil karya; dan (5)Fase 5: Menganalisis dan mengevaluasi proses pemecahan masalah. Dalam pembelajaran dengan PBL, siswa dibagi menjadi 6 kelompok dan masing-masing kelompok terdiri dari 5 siswa yang memiliki kemampuan akademis yang berbeda. Masing-masing kelompok diberikan 1 buah PC dengan kerusakan tertentu untuk diselesaikan melalui tahapan-tahapan PBL. 
Tabel 2. Aktivitas Guru Siklus I

\begin{tabular}{clcc}
\hline NO & Indikator & Juml. Item & Skor Perolehan \\
\hline 1 & Memberikan orientasi tentang permasalahan kepada siswa & 4 & 4 \\
2 & Mengorganisasi siswa untuk meneliti & 3 & 3 \\
3 & Membantu investigasi mandiri dan berkelompok & 5 & 5 \\
4 & Mengembangkan dan menyajikan hasil karya & 2 & 2 \\
5 & Menganalisis dan mengevaluasi proses pemecahan masalah. & 2 & 2 \\
\hline & Total & $\mathbf{1 6}$ & $\mathbf{1 6}$ \\
\hline
\end{tabular}

Tabel 3. Data observasi aktivitas siswa Siklus I

\begin{tabular}{clcc}
\hline NO & Indikator & Juml. Item & Skor Perolehan \\
\hline 1 & Belajar dalam lingkungan kelompok & 1 & 29 \\
2 & Bekerjasama dalam mendefinisikan masalah kerusakan PC & 2 & 46 \\
3 & Terlibat dalam Eksperimen dalam menyelesaikan masalah & 1 & 20 \\
& kerusakan PC & & \\
4 & Mencari informasi yang tepat & 2 & 33 \\
5 & Membuat kesimpulan & 2 & 32 \\
6 & Mempersiapkan laporan dan presentasi & 1 & 22 \\
7 & Mempresentasikan hasil eksperimen & 1 & 15 \\
\hline & Total & $\mathbf{1 0}$ & $\mathbf{1 9 7}$ \\
\hline
\end{tabular}

Tabel 4. Kategori Aktivitas Siswa dalam PBL Siklus I

\begin{tabular}{cccc}
\hline Skor Siswa & Kategori & Frekuensi & Frekuensi Relatif\% \\
\hline$X \geq 6,7$ & Sangat Tinggi & 17 & $59 \%$ \\
$6,7>X \geq 5$ & Tinggi & 5 & $17 \%$ \\
$5>X \geq 3,3$ & Rendah & 3 & $10 \%$ \\
$X<3,3$ & Sangat rendah & 4 & $14 \%$ \\
\hline Total & & 29 & $100 \%$ \\
\hline
\end{tabular}

Hasil perbaikan PC disajikan dalam lembar penyelesaian masalah dan dipresentasikan. Berikut disajikan data hasil penelitian

\section{Siklus I}

\section{Aktivitas guru dalam PBL}

Data aktivitas guru diperoleh dengan observasi selama pembelajaran berlangsung. Data disajikan pada tabel 2. Berdasarkan tabel 2 Skor perolehan aktivitas guru yakni 16 dari skor seharusnya yakni 16. Hal tersebut menunjukkan aktivitas guru dalam PBL sudah maksimal.

\section{Aktivitas siswa dalam PBL}

Data aktivitas siswa dalam PBL disajikan pada tabel 3. Berdasarkan tabel 3 diatas, skor perolehan aktivitas siswa 197 dari skor seharusnya 290. Prosentase skor aktivitas siswa dalam melaksanakan PBL yaitu $67,9 \%$. Prosentase tersebut menunjukkan bahwa aktivitas siswa dalam melaksanakan PBL belum berjalan dengan optimal. Pada tabel tersebut menunjukkan skor perolehan untuk masingmasing indikator belum mencapai target sehingga dapat disimpulkan bahwa pembelajaran belum berlngsung secara optimal. Perolehan skor aktivitas masing-masing siswa dalam PBL disajikan pada Tabel 4. 
Tabel 5. Data Keterampilan Berpikir Kritis siswa Siklus I

\begin{tabular}{clcc}
\hline No & \multicolumn{1}{c}{ Indikator } & $\begin{array}{c}\text { Jumlah } \\
\text { Item }\end{array}$ & $\begin{array}{c}\text { Skor } \\
\text { Perolehan }\end{array}$ \\
\hline 1 & Pertanyaannya jelas, cermat dan akurat terhadap masalah kerusakan PC & 2 & 41 \\
2 & $\begin{array}{l}\text { Mengumpulkan, menyelidiki, menilai dan mengolah informasi yang } \\
\text { relevan dan bernilai }\end{array}$ & 8 & 159 \\
3 & Berpikir reflektif/analogi & 3 & 66 \\
4 & Membuat kesimpulan yang logis(masuk akal), luas dan mendalam & 3 & 52 \\
5 & Berpemikiran terbuka & 5 & 108 \\
6 & Mampu mengkomunikasikan hasil pemikiran, solusi permasalahan & 4 & 73 \\
& dan saran & & \\
\hline & Total & $\mathbf{2 4}$ & $\mathbf{4 9 9}$ \\
\hline
\end{tabular}

Tabel 6. Kategori Keterampilan Berpikir Kritis Siswa Siklus I

\begin{tabular}{cccc}
\hline Skor Siswa & Kategori & Frekuensi & Frekuensi Relatif \% \\
\hline$X \geq 16,7$ & Sangat Tinggi & 16 & 55 \\
$16,7>X \geq 12,5$ & Tinggi & 4 & 14 \\
$12,5>X \geq 8,3$ & Rendah & 9 & 31 \\
$X<8,3$ & Sangat Rendah & 0 & 0 \\
\hline Total & & $\mathbf{2 9}$ & $\mathbf{1 0 0}$ \\
\hline
\end{tabular}

Berdasrkan tabel 4 dapat dianalisis aktivitas siswa dalam PBL pada kategori sangat tinggi sebesar 59\% (17), kategori tinggi 17\% (5), kategori rendah $10 \%$ (4) dan kategori sangat rendah $14 \%$ (4). Sehingga dapat disimpulkan siswa yang telah melaksanakan PBL dengan baik atau termasuk kategori tinggi adalah 22 siswa (76\%). Hasil tersebut menunjukkan bahwa pelaksanaan PBL belum berjalan optimal sehingga perlu untuk ditingkatkan.

\section{Keterampilan berpikir kritis siswa}

Data hasil observasi keterampilan berpikir kritis siswa pada siklus I disajikan pada tabel 5. Perolehan skor keterampilan berpikir kritis sebesar 499 dari skor seharusnya 725 , prosentase keterampilan berpikir kritis siswa yaitu $68,4 \%$. Data tersebut menunjukkan bahwa pencapaian skor indikator keterampilan berpikir kritis belum memenuhi kriteria yang ditetapkan sebesar $80 \%$.

Keterampilan berpikir kritis siswa dikategorikan dalam 4 kategori yaitu sangat tinggi, tinggi, rendah dan sangat rendah. Kategori keterampilan berpikir kritis siswa disajikan pada tabel 6.
Data tabel 6 menunjukkan bahwa keterampilan berpikir kritis siswa pada kategori sangat tinggi yaitu 16 siswa (55\%), kategori tinggi 4 siswa (14\%), kategori rendah yaitu 9 siswa $(31 \%)$ dan kategori sangat rendah yaitu 0 siswa ( $0 \%)$. Kriteria keberhasilan yang telah ditetapkan dalam penelitian ini yaitu sebanyak $80 \%$ atau 23 siswa dalam kategori tinggi. Dari data tabel 34 siswa yang termasuk pada kategori keterampilan berpikir kritis sangat tinggi dan tinggi yaitu 20 siswa atau sebesar $69 \%$, sehingga dapat disimpulkan bahwa pada siklus pertama untuk keterampilan berpikir kritis belum tercapai. Perlu ditingkatkan pada aspekaspek keterampilan berpikir kritis diatas.

\section{Hasil belajar siswa}

Data hasil belajar siswa yaitu hasil penilaian unjuk kerja. Aspek yang dinilai terdiri dari aspek persiapan, aspek proses kerja, hasil kerja, sikap kerja dan waktu. Perolehan nilai tertinggi 89,65 , nilai terrendah 50,50 dan nilai rata-rata 78,16. Berdasarkan data diatas jumlah siswa yang tuntas KKM yaitu sebanyak 20 siswa $(68,97 \%)$ sedangkan siswa yang belum tuntas KKM sebanyak 9 siswa $(31,03 \%)$. 
Tabel 7. Aktivitas Guru Siklus II

\begin{tabular}{clll}
\hline No & \multicolumn{1}{c}{ Indikator } & $\begin{array}{c}\text { Jumlah } \\
\text { Item }\end{array}$ & $\begin{array}{c}\text { Skor } \\
\text { Perolehan }\end{array}$ \\
\hline 1 & Memberikan orientasi tentang permasalahan kepada siswa & 4 & 4 \\
2 & Mengorganisasi siswa untuk meneliti & 3 & 3 \\
3 & Membantu investigasi mandiri dan berkelompok & 5 & 5 \\
4 & Mengembangkan dan menyajikan hasil karya & 2 & 2 \\
5 & Menganalisis dan mengevaluasi proses pemecahan masalah. & 2 & 2 \\
\hline & Total & 16 & 16 \\
\hline
\end{tabular}

Tabel 8. Data observasi aktivitas siswa dalam PBL Siklus II

\begin{tabular}{clccc}
\hline NO & \multicolumn{1}{c}{ Indikator } & $\begin{array}{c}\text { Jumlah } \\
\text { Item }\end{array}$ & $\begin{array}{c}\text { Skor } \\
\text { Seharusnya }\end{array}$ & $\begin{array}{c}\text { Skor } \\
\text { Perolehan }\end{array}$ \\
\hline 1 & Belajar dalam lingkungan kelompok & 1 & 29 & 29 \\
2 & $\begin{array}{l}\text { Bekerjasama dalam mendefinisikan masalah keru- } \\
\text { sakan PC }\end{array}$ & 2 & 58 & 52 \\
3 & $\begin{array}{l}\text { Terlibat dalam Eksperimen dalam menyelesaikan } \\
\text { masalah kerusakan PC }\end{array}$ & 1 & 29 & 26 \\
4 & Mencari informasi yang tepat & 2 & 58 & 42 \\
5 & Membuat kesimpulan & 2 & 58 & 44 \\
6 & Mempersiapkan laporan dan presentasi & 1 & 29 & 27 \\
7 & Mempresentasikan hasil eksperimen & 1 & 29 & 29 \\
\hline & Total & $\mathbf{1 0}$ & $\mathbf{2 9 0}$ & $\mathbf{2 4 9}$ \\
\hline
\end{tabular}

Tabel 9. Kategori aktivitas siswa dalam PBL Siklus II

\begin{tabular}{cccc}
\hline Skor Siswa & Kategori & Frekuensi & Frekuensi Relatif \% \\
\hline$X \geq 6,7$ & Sangat Tinggi & 24 & $82,8 \%$ \\
$6,7>X \geq 5$ & Tinggi & 5 & $17,2 \%$ \\
$5>X \geq 3,3$ & Rendah & 0 & $0 \%$ \\
$X<3,3$ & Sangat rendah & 0 & $0 \%$ \\
\hline
\end{tabular}

Dalam penelitian ini, pembelajaran dengan PBL dikatakan berhasil jika indikator keberhasilan telah tercapai yaitu $80 \%$ siswa tuntas KKM. Data diatas menunjukkan siswa yang tuntas KKM $(68,97 \%)$ sehingga perlu ada perbaikan dan peningkatan dalam pembelajaran dan perbaikan tersebut dilakukan pada siklus II.

\section{SIKLUS II}

\section{Aktivitas guru dalam PBL}

Data aktivitas guru pada siklus II disajikan pada tabel 7. Tabel 7 menunjukkan aktivitas guru dalam melaksanakan PBL skor yang diperoleh 16 dari skor seharusnya 16. Dalam pelaksanaan pembelajaran siklus II, guru telah melaksanakan keseluruhan fase-fase dalam PBL.

\section{Aktivitas siswa dalam PBL Siklus II}

Perolehan skor aktivitas siswa dalam PBL sebesar 249 dari skor seharusnya 290. Prosentase skor aktivitas siswa dalam melaksanakan PBL yaitu $85,92 \%$. Prosentase tersebut menunjukkan bahwa aktivitas siswa dalam melaksanakan PBL telah mengalami peningkatan lebih baik dari sikus I. Pada tabel 8 tersebut menunjukkan aktivitas siswa dalam pembelajaran PBL memperlihatkan peningkatan dari siklus I. Pencapaian skor untuk masing-masing siswa dikategorikan pada Tabel 9. 
Tabel 10 .Data Keterampilan Berpikir Kritis siswa Siklus II

\begin{tabular}{clccc}
\hline NO & \multicolumn{1}{c}{ Indikator } & $\begin{array}{c}\text { Jumlah } \\
\text { Item }\end{array}$ & $\begin{array}{c}\text { Skor } \\
\text { Seharusnya }\end{array}$ & $\begin{array}{c}\text { Skor } \\
\text { Perolehan }\end{array}$ \\
\hline 1 & $\begin{array}{l}\text { Pertanyaannya jelas, cermat dan akurat terha- } \\
\text { dap masalah kerusakan PC }\end{array}$ & 2 & 58 & 47 \\
2 & $\begin{array}{l}\text { Mengumpulkan, menyelidiki, menilai dan } \\
\text { mengolah informasi yang relevan dan bernilai }\end{array}$ & 8 & 232 & 174 \\
3 & $\begin{array}{l}\text { Berpikir reflektif/analogi } \\
4\end{array}$ & 3 & 87 & 80 \\
& $\begin{array}{l}\text { Membuat kesimpulan yang logis(masuk akal), } \\
\text { luas dan mendalam }\end{array}$ & 3 & 87 & 65 \\
5 & $\begin{array}{l}\text { Berpemikiran terbuka } \\
6\end{array}$ & 5 & 145 & 133 \\
& $\begin{array}{l}\text { Mampu mengkomunikasikan hasil pemikiran, } \\
\text { solusi permasalahan dan saran }\end{array}$ & 4 & 116 & 84 \\
\hline & Total & $\mathbf{2 5}$ & $\mathbf{7 2 5}$ & $\mathbf{5 8 3}$ \\
\hline
\end{tabular}

Tabel 11. Kategori Keterampilan berpikir kritis siswa Siklus II

\begin{tabular}{cccc}
\hline Skor Siswa & Kategori & Frekuensi & Frekuensi relatif \% \\
\hline$X \geq 16,7$ & Sangat Tinggi & 20 & $69 \%$ \\
$16,7>X \geq 12,5$ & Tinggi & 7 & $24,1 \%$ \\
$12,5>X \geq 8,3$ & Rendah & 2 & $6,9 \%$ \\
$X<8,3$ & Sangat Rendah & 0 & 0 \\
\hline Total & & 29 & 100 \\
\hline
\end{tabular}

Tabel 9 menunjukkan bahwa aktivitas siswa dalam PBL pada kategori sangat tinggi sebanyak 24 siswa $(82,8 \%)$ dan kategori tinggi sebanyak 5 siswa $(17,24 \%)$. Pada pelaksanaan siklus II, tidak ada siswa yang termasuk pada kategori rendah dan sangat rendah.

\section{Keterampilan berpikir kritis siswa Siklus II}

Perolehan skor keterampilan berpikir kritis pada siklus II mengalami peningkatan. Berdasarkan tabel 10, perolehan skor keterampilan berpikir kritis sebesar 583 dari skor seharusnya 725 , prosentase skor keterampilan berpikir kritis siswa yaitu $80,4 \%$. Data tersebut menunjukkan bahwa pencapaian skor indikator keterampilan berpikir kritis telah memenuhi kriteria yakni sebesar $80 \%$. Ketercapaian skor keterampilan berpikir kritis masing-masing siswa pada sikus II selanjutnya disajikan pada tabel 11.

\section{Hasil Belajar Siklus II}

Pada siklus II, perolehan nilai tertinggi 88,18 , nilai terrendah 78,38 dan rata-rata ni- lai 83,2. Berdasarkan data diatas jumlah siswa yang tuntas KKM yaitu sebanyak 29 siswa (100\%). Dalam penelitian ini, pembelajaran dengan PBL dikatakan berhasil jika indikator keberhasilan telah tercapai yaitu $80 \%$ siswa tuntas KKM. Data tersebut menunjukkan bahwa indikator keberhasilan telah terpenuhi.

\section{PEMBAHASAN}

Keterlaksanaan penerapan model problem based learning dalam pembelajaran materi perbaikan dan setting ulang PC

Penerapan pembelajaran dengan PBL dalam materi perbaikan dan setting ulang PC selama penelitian tindakan dapat dikatakan berjalan dengan lancar. Hasil yang diperoleh menunjukkan penerapan model PBL dalam meningkatkan keterampilan berpikir kritis dan hasil belajar berjalan dengan baik melalui perbaikan-perbaikan pada tiap siklusnya dan dapat mencapai tujuan pembelajaran. Pembelajaran dilaksanakan dalam dua siklus dimana pada 
tiap siklus terdiri dari lima fase PBL. Pembelajaran diawali dengan guru menjelaskan tujuan dari pelaksanaan pembelajaran dengan model PBL, menjelaskan perangkat yang dibutuhkan dalam PBL dan aktivitas-aktivitas yang akan dilaksanakan oleh guru dan siswa. Guru membagi kelas menjadi 6 kelompok. Masing-masing kelompok diberikan PC dengan jenis kerusakan berbeda-beda. Tiap kelompok harus menentukan sendiri tugas-tugas belajar apa saja yang dibutuhkan terkait dalam upaya menyelesaikan perbaikan PC dan juga menentukan peralatan dan bahan apasaja yang diperlukan dalam penyelesaian masalah. Dalam pembelajaran tersebut, peneliti berperan sebagai guru dan dibantu oleh seorang guru yang berperan sebagai kolaborator. Peran utama guru dalam PBL adalah sebagai fasilitator.

Siswa belajar dalam lingkungan kelompok untuk melaksanakan eksperimen perbaikan PC. Masing-masing kelompok melakukan penyelidikan terhadap kerusakan PC diawali dengan mengidentifikasi gejala kerusakan, menafsirkan gejala kerusakan dengan tepat, merumuskan langkah perbaikan dan melaksanakan perbaikan. Dalam tahapan ini siswa akan mempelajari tentang berbagai gejala kerusakan PC , makna gejala kerusakan PC dan langkah perbaikan yang tepat. Siswa harus menentukan sendiri komponen-komponen yang sesuai dengan spesifikasi PC pada kelompoknya. Perbaikan yang dilakukan antara kelompok satu dengan yang lain tidak sama persis karena permasalahan kerusakan PC yang diberikan adalah benar-benar berasal dari orang lain yang memang sedang rusak (kerusakan PC nyata). Siswa harus mampu memanfaatkan sumber referensi yang ada, karena masing-masing kelompok telah disediakan PC yang terhubung internet dan buku referensi. Sehingga siswa memperoleh pengalaman belajar yang secara langsung dialami. Pembelajaran dengan PBL diakhiri dengan masing-masing kelompok mempresentasikan hasil eksperimen perbaikan PC agar kelompok lain juga memperoleh pengetahuan baru dari kelompok lain.

Hasil pelaksanaan siklus I masih terdapat kekurangan pada aspek aktivitas siswa dalam PBL yang belum tercapai indikator keberhasilannya. Indikator yang paling rendah keterca- paiannya adalah pada kegiatan mempresentasikan hasil eksperimen. Siswa belum berani mengemukakan pendapat dan hasil pemikiran didepan kelas. Pada kegiatan membuat kesimpulan, bahwa keterlibatan siswa masih kurang, siswa masih mengandalkan anggota kelompok yang lain jika mengalami kesulitan dan cenderung pasif. Pada indikator 4 berkaitan dengan keaktifan siswa dalam menggunakan sumber belajar untuk menyelesaikan permasalahan. Dalam hal ini siswa cenderung menunggu jawaban dari guru ketika kesulitan dalam mendefinisikan dan menafsirkan gejala kerusakan PC, padahal dalam pembelajaran dengan PBL telah disiapkan fasilitas untuk mengakses berbagai informasi baik buku atau sumber di internet. Pada indikator 2 dan 3 keterlibatan siswa dalam eksperimen juga belum terpenuhi. Masih ditemukan siswa yang pasif dan masih ada dominasi pada saat praktik (belum merata). Skor aktivitas siswa dalam PBL pada kategori sangat tinggi sebanyak 17 siswa (59\%), kategori tinggi sebanyak 5 siswa (17\%), kategori rendah sebanyak 4 siswa $(10 \%)$ dan kategori sangat rendah sebanyak 4 siswa (14\%). Hal ini menunjukkan belum semua siswa terlibat secara optimal dalam pembelajaran.

Hasil refleksi dari siklus I menunjukkan bahwa pembelajaran dengan PBL belum berjalan dengan optimal meskipun berdasar observasi peran guru dalam menerapkan setiap langkah PBL telah maksimal. Oleh karena itu siklus II dirancang dengan merevisi dari siklus I.

Pelaksanaan siklus II dilakukan tiga kali pertemuan. Pada pembelajaran melaksanakan kelima fase PBL. Agar pembelajaran lebih optimal, guru menjelaskan kembali tujuan dari pelaksanaan PBL, aktivitas-aktivitas yang akan dilaksanakan oleh guru dan siswa. Untuk menghindari siswa yang pasif, maka guru mendorong masing-masing ketua kelompok untuk selalu melibatkan anggota kelompoknya dalam setiap tahapan pembelajaran. Untuk mendorong siswa yang masih pasif dalam pembelajaran dan presentasi, maka guru menunjuk siswa pada masing-masing kelompok untuk menjadi presenter utama dalam presentasi berikutnya agar semua siswa turut berperan dalam penyajian hasil eksperimen dan semua siswa mem- 
Tabel 12. Peningkatan aktivitas siswa dalam PBL

\begin{tabular}{clccc}
\hline NO & \multicolumn{1}{c}{ Indikator } & Siklus I & Siklus II \\
\hline 1 & Belajar dalam lingkungan kelompok & 29 & 29 \\
2 & $\begin{array}{l}\text { Bekerjasama dalam mendefinisikan masalah kerusakan PC } \\
3\end{array}$ & $\begin{array}{l}\text { Terlibat dalam Eksperimen dalam menyelesaikan masalah } \\
\text { kerusakan PC }\end{array}$ & 46 & 52 \\
4 & Mencari informasi yang tepat & 33 & 26 \\
5 & Membuat kesimpulan & 32 & 42 \\
6 & Mempersiapkan laporan dan presentasi & 22 & 27 \\
7 & Mempresentasikan hasil eksperimen & 15 & 29 \\
\hline & Total & 197 & 249 \\
\hline
\end{tabular}

Tabel 13. Peningkatan Skor Siswa

\begin{tabular}{cccc}
\hline Skor Siswa & Kategori & Frekuensi Siklus I & Frekuensi Siklus II \\
\hline$X \geq 6,7$ & Sangat Tinggi & 17 & 24 \\
$6,7>X \geq 5$ & Tinggi & 5 & 5 \\
$5>X \geq 3,3$ & Rendah & 3 & 0 \\
$X<3,3$ & Sangat rendah & 4 & 0 \\
\hline Total & & 29 & 29 \\
\hline
\end{tabular}

peroleh kesempatan untuk mengungkapkan hasil pemikiran.

Hasil pelaksanaan siklus II menunjukkan peningkatan yang lebih baik. Indikator-indikator aktivitas siswa yang sebelumnya belum terpenuhi mengalami peningkatan. Ketercapaian pembelajaran dengan PBL pada siklus II perolehan skor sebesar 249 dari skor seharusnya 290 , prosentase keberhasilan $85,9 \%$. Secara ringkas, data peningkatan aktivitas siswa disajikan pada tabel 12 .

Perolehan skor masing-masing siswa dalam melaksanakan PBL juga mengalami peningkatan. Pada akhir siklus II aktivitas siswa dalam melaksanakan PBL berada pada kategori tinggi. Data ditunjukkan pada tabel 13.

Berdasarkan tabel 13 diatas menunjukkan bahwa pada akhir siklus II, seluruh siswa telah melaksanakan PBL dengan baik. Hal ini ditunjukkan dengan perolehan skor siswa pada kategori tinggi sebanyak 29 siswa.

\section{Keterampilan berpikir kritis siswa setelah penerapan model problem based learning}

Keterampilan berpikir kritis dalam penelitian ini merupakan keterampilan menggunakan aspek-aspek berpikir yang terdiri dari 6 indi- kator yaitu Indikator 1 pertanyaannya jelas, cermat dan akurat terhadap masalah kerusakan PC; indikator 2 mengumpulkan, menyelidiki, menilai dan mengolah informasi yang relevan dan bernilai ; indikator 3 berpikir reflektif/ analogi; indikator 4membuat kesimpulan yang logis(masuk akal), luas dan mendalam ; indikator 5 berpemikiran terbuka; indikator 6 mampu mengkomunikasikan hasil pemikiran, solusi permasalahan dan saran. Indikator-indikator diatsa terkait dengan proses-proses yang dipelajari dalam materi perbaikan PC. Agar perbaikan PC dapat dilaksanakan dengan tepat maka siswa harus dapat melihat permasalahan kerusakan PC dengan rinci terhadap gejala kerusakan dengan akurat, mengidentifikasi dengan luas dan mendalam, mengolah informasi kerusakan PC dengan tepat sehingga dapat merumuskan langkah perbaikan dengan tepat.

Pelaksanaan PBL untuk meningkatkan keterampilan berpikir kritis dalam penelitian siklus I data menunjukkan bahwa beberapa indikator masih belum terpenuhi atau skor perolehan masih kurang. Ketercapaian indikator 1 pertanyaan jelas, cermat dan akurat terhadap masalah kerusakan PC sebesar 41 (70,7\%); indikator 2 mengumpulkan, meny- 
elidiki, menilai dan mengolah informasi yang relevan dan bernilai sebesar $159(68,5 \%)$; indikator 3 berpikir reflektif/analogi sebesar 66 $(75,8 \%)$; indikator 4 membuat kesimpulan yang logis(masuk akal), luas dan mendalam sebesar 52 (59,8\%); indikator 5 berpemikiran terbuka sebesar $108(74,5 \%)$;dan indikator 6 mampu mengkomunikasikan hasil pemikiran, solusi permasalahan dan saran $73(62,9 \%)$. Berdasarkan data diatas perolehan skor sebesar 499 dari skor seharusnya 729, prosentase keterampilan berpikir kritis siswa yaitu $68,4 \%$. Data tersebut menunjukkan bahwa pencapaian skor indikator keterampilan berpikir kritis belum memenuhi kriteria yakni sebesar $80 \%$. Dilihat dari skor perolehan masing-masing siswa keterampilan berpikir kritis siswa pada kategori sangat tinggi yaitu 16 siswa (55\%), kategori tinggi 4 siswa (14\%), kategori rendah yaitu 9 siswa (31\%) dan kategori sangat rendah yaitu 0 siswa $(0 \%)$. Kriteria keberhasilan yang telah ditetapkan dalam penelitian ini yaitu sebanyak $80 \%$ atau 23 siswa dalam kategori tinggi. Dapat disimpulkan bahwa pada siklus pertama untuk kriteria keberhasilan keterampilan berpikir kritis belum tercapai.

Keterampilan berpikir kritis yang diterapkan dalam pembelajaran materi perbaikan dan setting ulang PC sebenarnya membantu siswa dalam upaya menyelesaikan permasalahan kerusakan PC. Untuk dapat merumuskan solusi perbaikan dan juga kesimpulan maka harus diawali dengan mengidentifikasi melalui mengajukan pertanyaan yang tepat seperti : bagaimanakah kondisi hardware komponen PC?; Apakah terdapat bunyi beep kode kesalahan?; apakah ada tampilan pada monitor?; apakah tidak berfungsinya power supply disebabkan karena rusaknya komponen power supply; dan pertanyaan lain yang mengarah pada penyelidikan yang tepat. Bermula dari pertanyaan tepat yang diajukan akan menjadi petunjuk bagi siswa dalam melakukan langkah-langkah penyelidikan berikutnya. Pada pelaksanaan data observasi menunjukkan bahwa dalam mengawali eksperimen perbaikan PC, siswa belum dapat mengajukan pertanyaan tepat dan dalam mengidentifikasi belum mendalam. Selanjutnya pada indikator mengumpulkan, menyelidiki, menilai dan mengolah informasi yang relevan dan bernilai, siswa belum dapat menilai dengan tepat informasi gejala kerusakan PC yang muncul karena ada kesalahan awal dari proses identifikasi sehingga informasi yang diperoleh belum tepat. Hal yang tidak kalah penting dalam indikator keterampilan berpikir kritis adalah siswa mampu mengkomunikasikan hasil pemikiran, solusi permasalahan kerusakan PC yang telah didapatkan. Pada indikator ini, ketercapaian skor masih tergolong rendah. Siswa masih belum berani mengungkapkan hasil pemikiran didepan oranglain, karena khawatir melakukan kesalahan. Kesimpulan pada siklus I aspek keterampilan berpikir kritis siswa masih kurang, dilihat dari skor total ketercapaian adalah $68,4 \%$. Berdasarkan hasil tersebut dalam pelaksanaan PBL perlu dilakukan perbaikan dan diperbaiki pada pelaksanaan siklus II. Pelaksanaan pada siklus II guru fokus dalam peninkatan ketercapaian indikator diatas tetapi tetap meningkatkan indikator yang telah terpenuhi.

Pelaksanaan siklus II, guru dan kolaborator meningkatkan perannya sebagai fasilitator. Guru membantu kelompok yang kesulitan dengan mengajukan pertanyaan yang dapat memacu proses penyelidikan yang lain. Memberi contoh bagaimana mengaitkan secara logis adanya gejala kerusakan PC dengan kelanjutan penyelidikan lain. Melalui hal tersebut siswa terdorong untuk menggunakan keterampilan dalam mengaitkan secara logis gejala kerusakan yang ada. Selain itu apabila ada siswa atau kelompok yang bertanya atau mengalami kesulitan maka guru mengrahkan siswa untuk mencari sumber referensi yang tepat dan mendampingi dalam pencarian tersebut. Selanjutnya agar semua siswa terlibat dalam mengkomunikasikan hasil pemikiran, pada saat presentasi berlangsung guru mengajukan pertanyaan-pertanyaan untuk memancing siswa yang belum aktif agar mampu mengkomunikasikan dan menjelaskan hasil pemikiran terhadap eksperimen perbaikan PC yang telah dilaksanakan.

Hasil pelaksanaan siklus II pada aspek keterampilan berpikir kritis menunjukkan peningkatan. Perolehan skor sebesar 583 dari skor seharusnya 729 , prosentase keterampilan berpikir kritis siswa sebesar 80,4\%. Berdasarkan perolehan skor diatas menunjukkan bahwa kriteria keberhasilan telah tercapai. Masing- 
Tabel 14. Peningkatan Keterampilan Berpikir Kritis Siswa Tiap Indikator

\begin{tabular}{clcc}
\hline NO & \multicolumn{1}{c}{ Indikator } & Siklus I & Siklus II \\
\hline 1 & $\begin{array}{l}\text { Pertanyaannya jelas, cermat dan akurat terhadap masalah } \\
\text { kerusakan PC }\end{array}$ & 41 & 47 \\
2 & $\begin{array}{l}\text { Mengumpulkan, menyelidiki, menilai dan mengolah infor- } \\
\text { masi yang relevan dan bernilai }\end{array}$ & 159 & 174 \\
3 & $\begin{array}{l}\text { Berpikir reflektif/analogi } \\
4\end{array}$ & 66 & 80 \\
& $\begin{array}{l}\text { Membuat kesimpulan yang logis(masuk akal), luas dan men- } \\
\text { dalam }\end{array}$ & 52 & 65 \\
5 & $\begin{array}{l}\text { Berpemikiran terbuka } \\
6\end{array}$ & 108 & 133 \\
& Mampu mengkomunikasikan hasil pemikiran, solusi perma- \\
salahan dan saran & 73 & 84 \\
\hline Skor Total & $\mathbf{4 9 9}$ & $\mathbf{5 8 3}$ \\
\hline
\end{tabular}

Tabel 15. Peningkatan Skor Keterampilan berpikir Kritis Siswa

\begin{tabular}{cccc}
\hline Skor Siswa & Kategori & Frekuensi Siklus I & Frekuensi Siklus II \\
\hline$X \geq 16,7$ & Sangat Tinggi & 16 & 20 \\
$16,7>X \geq 12,5$ & Tinggi & 4 & 7 \\
$12,5>X \geq 8,3$ & Rendah & 9 & 2 \\
$X<8,3$ & Sangat Rendah & 0 & 0 \\
\hline Total & & $\mathbf{2 9}$ & $\mathbf{2 9}$ \\
\hline
\end{tabular}

masing indikator keterampilan berpikir kritis mengalami peningkatan. Data peningkatan keterampilan berpikir kritis siswa disajikan pada tabel 14.

Skor perolehan keterampilan berpikir kritis masing-masing siswa mengalami peningkatan. Pada akhir siklus II kategori keterampilan berpikir kritis mengalami peningkatan. Keterampilan berpikir kritis siswa kategori sangat tinggi sebanyak 20 siswa (69\%), kategori tinggi sebanyak siswa $7 \quad(24,1 \%)$, kategori rendah sebanyak 2 siswa $(6,9 \%)$, kategori sangat rendah sebanyak 0 siswa ( $0 \%)$. Siswa yang telah mencapai keterampilan berpikir kritis kategori tinggi yaitu 27 siswa $(93,1 \%)$ dengan kata lain kriteria keberhasilan pada siklus II telah tercapai. Data peningkatan keterampilan berpikir kritis masing-masing siswa disajikan pada tabel 15 .

Meningkatnya jumlah siswa yang termasuk pada kategori tinggi dikarenakan siswa telah dapat menerapkan tahap-tahapan dalam berpikir kritis melalui PBL. Melalui permasalahan yang disajikan dalam PBL siswa dapat lebih terlibat dalam upaya menyelesaikan per- masalahan dan terlibat untuk menggunakan keterampilan berpikir kritis.

\section{Hasil belajar siswa setelah penerapan model problem based learning}

Berhasil atau tidaknya pembelajaran dengan model PBL pada siswa dianalisis dengan melihat hasil tes. Diakhir penerapan PBL, dilakukan tes unjuk kerja untuk mengetahui apakah materi pembelajaran dapat terserap. Tes unjuk kerja dilaksanakan dua kali yaitu diakhir siklus I dan diakhir siklus II. Tes unjuk kerja merupakan tes untuk melihat unjuk kerja siswa dalam melaksanakan tahap-tahap dalam perbaikan PC. Tes dilaksanakan secara individu sehingga guru dapat mengetahui siswa yang belum dapat menyerap materi, dan dapat melihat secara rinci aspek mana saja yang masih kurang.

Hasil penilaian pada siklus I menunjukkan bahwa nilai tertinggi 89,65 , nilai terrendah 50,50, nilai rata-rata 78,16 . Jumlah siswa yang tuntas KKM yaitu 21 siswa $(68,97 \%)$ dan siswa yang belum tuntas KKM 9 siswa $(31,03 \%)$. Dilihat dari rekapitulasi nilai untuk 
Tabel 16. Peningkatan Hasil Belajar Siswa

\begin{tabular}{llcc}
\hline No & Keterangan & Siklus I & SiklusII \\
\hline 1 & Nilai Tertinggi & 89,65 & 88,8 \\
2 & Nilai Terrendah & 50,50 & 78,38 \\
3 & Rata-rata & 78,16 & 83,2 \\
4 & Tuntas $(\mathrm{N} \geq 75)$ & $21(68,97 \%)$ & $29(100 \%)$ \\
5 & Belum Tuntas $(\mathrm{N}<75)$ & $9(31,03 \%)$ & $0(0 \%)$ \\
\hline
\end{tabular}

tiap indikator unjuk kerja, masih ada siswa yang memperoleh skor nol (0) pada aspek sikap kerja, hasil kerja dan waktu. Hal ini dikarenakan ada siswa yang pada saat penilaian unjuk kerja kurang menerapkan keselamatan kerja sehingga pada saat ujicoba PC terdapat komponen Random Access Memory (RAM) yang terbakar karena pemasangan pada slot memori kurang tepat. Kesalahan tersebut menyebabkan PC tidak dapat selesai diperbaiki karena waktu telah habis sehingga komponen penilaian hasil kerja dan waktu juga memperoleh nilai nol (0).

Mempertimbangkan hasil dari penilaian unjuk kerja siklus I, guru kemudian memberikan penjelasan kepada siswa pentingnya menerapkan keselamatan kerja pada saat praktik demi keamanan dan keselamatan peralatan dan diri sendiri. Agar siswa dalam menyelesaikan permasalahan PC dapat memanfaatkan waktu yang disediakan, guru memotivasi siswa agar menggunakan teknik pada keterampilan berpikir kritis sehingga dapat fokus menyelesaikan perbaikan sesuai dengan hasil identifikasi yang tepat dan akurat.

Hasil penilaian menunjukkan peningkatan penilaian pada aspek-aspek yang sebelumnya masih kurang. Berdasarkan rekapitulasi data diperoleh nilai tertinggi 88,18 , nilai terrendah 78,38 , nilai rata-rata 83,2 . Jumlah siswa yang mencapai nilai KKM yaitu 29 siswa (100 Data peningkatan nilai hasil belajar dan rata-rata nilai disajikan pada tabel 16 .

Peningkatan hasil belajar siswa pada siklus II terkait dengan semakin meningkatnya penguasaan siswa pada langkah-langkah perbaikan PC dengan menggunakan keterampilan berpikir kritis melalui penerapan PBL. Selain itu pada siklus II siswa berupaya meningkatkan keterlibatan dalam pembalajaran PBL dalam eksperimen mencari penyelesaian masalah kerusakan PC. Siswa juga telah dapat memanfaatkan adanya sumber refferensi yang akan membantu dalam menyelesaikan permasalahan kerusakan PC. Peningkatan aktivitas siswa dalam pembelajaran menjadikan pengetahuan siswa bertambah sehingga pada saat menyelesaikan permasalahan kerusakan PC, siswa dapat menerapkan tahapan-tahapan untuk melaksanakan perbaikan PC dengan tepat.

\section{SIMPULAN DAN SARAN}

\section{Simpulan}

Berdasarkan penelitian yang telah dilaksanakan dan data-data yang diperoleh, peneliti dapat menarik kesimpulan sebagai berikut:

1. Melalui penerapan model problem based learning dalam pembelajaran materi perbaikan dan setting ulang PC dalam penelitian ini dapat meningkatkan keterampilan berpikir kritis siswa dalam pembelajaran.

2. Melalui penerapan model problem based learning dalam pembelajaran materi perbaikan dan setting ulang PC dalam penelitian ini dapat meningkatkan hasil belajar siswa .

3. Keterampilan berpikir kritis siswa setelah penerapan problem based learning meningkat sebesar $24,2 \%$. Jumlah siswa dengan kategori keterampilan berpikir kritis tinggi pada akhir siklus II yaitu sebanyak 27 siswa $(93,1 \%)$.

4. Peningkatan hasil belajar siswa setelah penerapan problem based learning yakni sebesar 31,03\%. Jumlah siswa yang mencapai KKM pada akhir siklus II yakni sebanyak 29 siswa (100\%).

\section{Saran}

Berdasarkan kesimpulan beberapa saran yang dapat diberikan tentang penerapan PBL sebagai berikut: 
1. Bagi Guru

a. Apabila akan menerapkan model PBL dalam pembelajaran sebaiknya guru membuat perencanaan dan persiapan pelaksanaan PBL dengan baik dalam waktu yang cukup dan pemilihan materi yang tepat. Karena tidak semua materi cocok untuk diterapkan dengan PBL.

b. Guru perlu membuat suatu panduan tertulis tentang langkah-langkah PBL, aktivitas apa saja yang akan dilaksanakan, jadwal pelaksanaan, serta perangkat-perangkat yang dibutuhkan. Sehingga melalui panduan tersebut guru akan lebih mudah mensosialisasikan pada siswa, dan siswa dapat mempelajari terlebih dahulu sebelum PBL dimulai.

\section{Sekolah}

Memberikan pengetahuan dan wawasan kepada guru tentang penggunaan model PBL dalam pembelajaran praktik di SMK. Sehingga guru dapat memilih model pembelajaran yang sesuai dengan karakteristik materi yang akan diajarkan. Dengan demikian maka proses pembelajaran praktik kejuruan menjadi lebih optimal.

\section{Peneliti}

Kepada peneliti lain yang membaca penelitian ini dan bermaksud untuk mengembangkan temuan lebih lanjut, diharapkan dapat melakukan penelitian dengan penerapan PBL pada pembelajaran standar kompetensi yang lain dan dengan lebih banyak menggunakan sampel penelitian sehingga hasilnya akan lebih luas dan memungkinkan untuk digeneralisasi.

\section{DAFTAR PUSTAKA}

Akinoglu, O., \& Tandogan, R. O. (2007). The effects of problem-based active learning in science education on student's academic achievement, attitude and concept learning. Eurasia Journal of Mathematics, Science \& Technology Education, 3 (1), 71-81.

Arends, R. I. (2008). Belajar untuk mengajar. (Terjemahan Helly Prajitno Soetjipto \&
Sri Mulyantini Soetjipto). New York: McGraw Hills. (Buku asli diterbitkan tahun 2007).

Dimyati \& Mudjiono. (2009). Belajar dan pembelajaran. Jakarta: Rineka Cipta.

Gafar, A. A. \& Ridwan, T. (2008). Implementasi problem based learning (PBL) pada proses pembelajaran di BPTP Bandung. Jurnal Universitas Pendidikan Indonesia, Nomor VII, 12.

Gerald Choon-Huat Koh ., Hoon Eng Khoo., Mee Lian Wong., et.al. (2008). The effects of problem-based learning during medical school on physician competency: a systematic review. Canadian Medical Association Journal, 178 (1), 34-41.

Glazer, E. (2001). Problem based instruction. In M. Orey (Ed.), Emerging perspective on learning, teaching, and technology. Diambil dari http//www.coe.uga.edu/ epltt/ProblemBasedInstruct.htm.

Hamalik, O. (2011). Proses belajar mengajar. Jakarta: Bumi Aksara.

Hasrul Bakri. (2009). Peningkatan minat belajar praktek menggulung trafo melalui pendekatan pembelajaran berbasis masalah (PBL) pada siswa Smk Negeri 3 Makassar. Jurnal Medtek Vol 1 Nomor 1 April, 2-8.

J. Oja, K. (2011). Using problem-based learning in the clinical setting to improve nursing students' critical thinking: An evidence review. Journal of Nursing Education Vol. 50, No. 3.

Kay, K. (2008). Preparing every child for the 21st century. APEC Ed Ne-Xi'an (Symposium) Xi'an China, January 17.

McTaggart, R. (1995). Action research: a short modern history. Victoria: Deakin University Press.

Nitko, J.A., \& Brookhart, M. S. (2011). Educational assesment of student. Boston: Pearson Education. 
Pardjono. (2007). Panduan penelitian tindakan kelas. Yogyakarta: Lembaga Penelitian UNY.

Paul, R., \& Elder, L. (2008). Miniatur guide to critical thinking concepts and tools. Dillon Beach: Foundation for Critical Thinking Press.

Pavlova, M. (2009). Technology and vocational education for sustainable development- empowering individuals for the future. New York: Springer Science \& Business Media B.V.

Sadia, I. W. (2008). Model pembelajaran yang efektif untuk meningkatkan ketrampilan berpikir kritis. Jurnal Pendidikan dan Pengajaran UNDIKSHA, No.2 Th XXXXI 13-15.
Sudira, P. (2006). Pembelajaran di Sekolah Menengah Kejuruan. Depdiknas: Direktorat Jenderal Manajemen Pendidikan Dasar dan Menengah Direktorat Pembinaan Sekolah Menengah Kejuruan Subdit Pembelajaran.

Tan, O.S. (2008). Problem-based learning and creativity. Singapore: Cengage Learning.

Teaching and Learning Bulletin. (Vol. 7 no. 3, 2004). Problem-based Learning. Diambil pada tanggal 15 Januari 2013, dari http://depts.washington.edu/cidrweb/ teaching/files/2012/12/PBL.pdf.

Winkel, W.S. (2009). Psikologi pengajaran. Yogyakarta: Media Abadi.

Woolfolk, A. (2004). Educational psychology (9th ed.). New York: Pearson. 